\title{
DISPUTE SETTLEMENT NORM OF ESTATE DISTRIBUTION ON ADAT PEOPLE OF MINANGKABAU (WEST SUMATRA) ${ }^{\Omega}$
}

\author{
Ellyne Dwi Poespasari \\ Faculty of Law Universitas Airlangga, Indonesia \\ E-mail: ellynefh.unair@ymail.com
}

\begin{abstract}
Principally, dispute settlement of estate distribution on Minangkabau People is done by deliberation. If its settlement through deliberation is failed, an effort to solve the dispute through court needs to be conducted. This paper studies first, how is the opinion of judicial institution in the dispute of estate distribution on Minangkabau people; second, how is the implication of estate distribution on Minangkabau people after judge's verdict. This is normative research with statute approach and case approach. The result of this research shows that there is possibility of judicial institution's verdict in the dispute settlement of estate distribution which is contradicted with adat law of Minangkabau (Matrilineal kinship). However, if it is seen from legal perspective, estate distribution of Minangkabau people after judge's verdict can be a breakthrough that is able to change the value of old adat law into the new one.
\end{abstract}

Keywords: Dispute settlement, estate distribution, matrilineal kinship.

\begin{abstract}
Abstrak
Secara prinsip, penyelesaian sengketa pembagian harta waris Masyarakat Minangkabau dilakukan secara musyawarah mufakat. Jika penyelesaiannya secara musyawarah mufakat gagal, maka diperlukan upaya untuk menyelesaikan sengketa melalaui pengadilan. Tulisan ini mengkaji pertama, bagaimana pendapat lembaga peradilan dalam sengketa pembagian harta waris pada masyarakat Minangkabau; Kedua, bagaimanakah implikasi pembagian harta waris pada masyarakat Minangkabau pasca putusan hakim. Penelitian ini merupakan penelitian normatif dengan pendekatan perundang-undangan dan pendekatan kasus. Hasil penelitian menunjukkan bahwa terdapat kemungkinan putusan lembaga peradilan dalam penyelesaian sengketa pembagian harta waris bertentangan dengan hukum adat Minangkabau (kekerabatan Matrilineal). Namun apabila dicermati dari perpektif hukum, pembagian harta waris Minangkabau pasca putusan hakim dapat menjadi terobosan yang dapat merubah nilai hukum adat yang lama ke arah nilai hukum adat yang baru.
\end{abstract}

Kata Kunci : penyelesaian sengketa, pembagian harta waris, kekerabatan matrilineal.

\section{Introduction}

Heredity law of Minangkabau people is influenced by the matrilineal kinship system, in which the position of the girls is more prominent than the boys. ${ }^{1}$ In this matrilineal kinship system, it is common to do semenda marriage. This means that after marriage, the husband will follow his wife but still becoming the mem-

$\Omega \quad$ Kontrak Penelitian Unggulan Perguruan Tinggi (PUPT) Year 2017 Number:597/UN3.14/LT/2017, or Keputusan Rektor Universitas Airlangga Number 586/UN3/2017 on Pelaksanaan Penelitian Universitas Airlangga Year 2017.

Lastuti Abubakar, "Revitalisasi Hukum Adat Sebagai Sumber Hukum Dalam Membangun Sistem Hukum Indonesia", Jurnal Dinamika Hukum, Vol. 13 No. 2 May 2013, p. 327. ber of his original relative and not being the part of his wife's relative. Then, the children follow the members of their mother's relatives. ${ }^{2}$

In Minangkabau society, estate is divided into four parts, namely: first, high treasure, which is the treasure inherited hereditarily from generations to generations according to maternal lineage. High treasure in Minangkabau is a gadang house or heirloom rice field which belongs to the people in which the mother becomes the center of the authority. Principally,

Komari, "Eksistensi Hukum Waris Di Indonesia: Antara Adat dan syariat”, Jurnal Asy-Syari ‘ah, Vol. 17 No. 2, August 2015, p. 160. 
high treasure cannot be shared and sold. The exception is when someone is in a condition where he or she is forced to pawn it. Second, low treasure is the treasure of one or two generations of relatives, like the treasure that comes from one grandfather or a descendant's grandmother. Low treasure is a treasure owned together by the relatives in which its ownership cannot be divided and it will continuously increase along with the income of the wealth of its heirs. ${ }^{3}$ Minangkabau Adat Law states that low treasure is the treasure derived from the result of work. This property can be sold and mortgaged according to the requirement with agreement of its heirs. ${ }^{4}$ Third, livelihood treasure is a treasure earned with gold. ${ }^{5}$ Livelihood treasure is the husband-wife's livelihood earned during marriage. It is acquired by buying or in terms of adat is called golden fields of rice fields, fields, gardens and others. When divorce occurs, these livelihood treasures can be shared; Fourth, Suarang Treasure. ${ }^{6}$ The origin of the word Suarang is from "surang" or "a person", so the property of suarang is the property owned by a person, either by husband or wife before the marriage. After marriage, the status of this property still belongs to each individual. Thus, this suarang treasure is the innate property of the husband and wife, and it is a treasure of precision. Since this treasure belongs to "surang" or private property, then the treasure can be given to others without being bound to their husband or wife. Therefore, in tradition, it is said "suarang baragiah, pancaharian dibagi" (suarang can be given, livelihood can be divided). The meaning of a person can be given to anyone, but the livelihood can be divided if there is divorce.

In matrilineal kinship systems, heirs are based on female lineage or maternal line. The-

3 Engrina Fauzi, "Dualisme Pelaksanaan Pembagian Harta Waris Di Minangkabau Dalam Persektif Hukum Islam dan Hukum Adat", Jurnal Ilmu Hukum Yustisia, Vol. 24 No 2, 2016, p. 208.

4 Anwar Fauzi, "Dualitas Hukum Waris Minangkabau Dan Islam (Studi Konstruksi Sosial Masyarakat Muslim Minangkabau Di Malang)", Jurisdictie, Jurnal Hukum dan Syariah, Vol. 3 No. 1, June 2012, p. 45-54.

5 Engrina Fauzi, Op.Cit., p. 219.

6 Hilman Hadikusuma, 1993, Hukum Waris Adat, Bandung: Citra Aditya Bakti, p. 38-39. refore, all children can only be the heirs of their own mother, both for high treasures and for low treasures. If the deceased is a man or the husband, then his son and his widow will not be the heirs to the husband's estate, but the heirs are all her nephews (children of his sisters).

In the matrilineal kinship system, there is problem when estate disputes occur. Such disputes may occur in the case of the determination of the heirs of the testator. The source of the problem is the matrilineal system based on maternal lineage, the grandmother continues in the lineup, so the husband does not get the heirs of the testator. This condition happens because female heirs are higher than male heirs.

One of the cases in Minangkabau society in the dispute of estate distribution is kincir padi (rice mill) case. In this case, there was a dispute between a woman named Kalek (Pisang tribe, Batipuh Buruh, Padang Panjang) as the widow of the deceased Ibrahim with Datuk Mudo's title deal with Abdul Rahman with Datuk Mudo's title (the mother of heir in the family) and two women named Nursiah and Nursilah, in which the three of them come from the Koto tribe, Batipuh Ateh, Padang Panjang. Initially, the case was resolved through consensus and deliberation in front of the families, relatives and society. However, the deliberation experienced failure and difficulties and it did not bring the result that eventually the case became a dispute in the District Court and recorded at the District Court of Padang Panjang with Civil Registration Number 11/1962.

Another case that keeps happening is dispute of estate (high treasure). High treasure in Minangkabau matrilineal relationship cannot be shared individually, since principally it is inherited collectively. This makes high treasure become dispute. In resolving the dispute of estate especially about high treasure, Minangkabau society can solve it through Kerapatan Adat $\mathrm{Na}$ gari (KAN). Kerapatan Adat Nagari can be used as dispute settlement method beside court. Meriza Elpha states that customary justice is a process, way to judge and settle peacefully done 
by some kinds of agency or institution outside the court as regulated in Law Number 48 Year 2009 on Judicial Power. ${ }^{7}$

This research will focus on the development of dispute settlement norm of estate distribution in Minangkabau society after judge's verdict. Basically, the position of woman is higher than man (son is not the hereditary successor). In this case, son and daughter still get estate from the mother. The estate from father is inherited to his sister and niece. Along with the development of legal norm through court's verdict, the position of man as father (parent) and husband in family will affect the existing matrilineal system.

Based on the background above, there are two research questions. First, how is the opinion of judicial institution about the dispute of estate distribution on Minangkabau society?; and second, how is the implication of estate distribution on Minangkabau society after judge's verdict?.

\section{Research Method}

The type of this research is normative research by using statute approach and case approach. ${ }^{8}$ Statute approach is used to analyze the legislation and jurisprudence or judge's verdict. Case approach is used to analyze the case that has been given the fixed judge's verdict based on heredity law of Minangkabau society. The legal materials of this research are first, primary legal material from legislations in the field of judicial power, the Jurisprudence of Supreme Court (Judge's Verdict), meanwhile the secondary legal material is obtained from heredity law literature, article, scientific journal in the field of heredity law. To analyze legal materials, the researcher uses descriptive analysis method. This method focuses on explaining and analyzing the problems so that it leads to the conclusion that is reliable.

Meriza Elpha, "Peran Datuk Pemuka Adat Sebagai Mediator Dalam Penyelesaian Sengketa Harta Pusaka (Harta Soko) Di Kabupaten Kampar", Jurnal Ilmu Hukum UNRI, Vol. 6 No. 1, August 2015-January 2016, p. 173.

8 Peter Mahmud Marzuki, 2005, Penelitian Hukum, Jakarta: Prenada, p. 28.

\section{Result and Discussion}

Generally, Minangkabau society wants to settle that problem through harmonious and peaceful deliberation as well as involving many parties, not only the parties which havedispute but also all members of the deceased heir. However, if the effort to do the peaceful deliberation goes into failure and difficulty, the case will be brought to trial. Thus, it will be the duty of judge of district court, judge of high court and Supreme Court to find the appropriate solution about the dispute.

\section{Opinion of Judicial Institution in the Dispute} of Estate Distribution on Minangkabau Society

According to Soepomo, adat law is a nonwritten law in unstatutory law, including life regulations that are not regulated by the authority, but still obeyed and supported by society based on their beliefs that those regulations have the power of law. ${ }^{9}$ Therefore, the existing law as the convention in legal institutions appears because of judge made law. In this case, the existing law is created as custom rules that are maintained in social life either in cities or villages (customary law). Based on that, customary law is an essential legal norm having roots in cultural values of Indonesian nation throughout the history experiencing settlement with certain condition. It means that customary law is open to any norm as long as it is not contradicted with customs and cultural values of Indonesian nation itself.

In the court, in settling the dispute of estate distribution, the judge has to notice the original and non-written regulations of heredity law of Minangkabau society. This law construction becomes the basic for judge to discover the law in settling that case. Legal discovery done by judge in deciding the case is reviewing first whether the case is regulated in Law or not. If the Law is not complete and clear, the judge has to find the law by himself. Its implycation is the judge has to do legal discovery

9 Soepomo, 2003, Bab-Bab Tentang Hukum Adat, Jakarta: Pradnya Paramita, p. 41. 
(rechtsvinding) and the judge is assigned to apply the common law in concrete legal case. ${ }^{10}$

Article 5 paragraph (1) of Law Number 48 Year 2009 on Judicial Power states that "Judges and constitutional judges must explore, follow, and understand the law value and sense of justice which live in society". In order to explore sense of justice in society, there is the time for judge decided a case by looking at customary law. Condition demands judge to have high intellectuality about existing law in society which is unwritten but obeyed and respected. Furthermore, in Article 50 Paragraph (1) of Law Number 48 Year 2009 on Judicial Power explains "Court decision must contain a reason about the decision also contain a particular Article from related regulation or unwritten law source to be foundation to adjudicate".

Related to dispute settlement of estate distribution in Minangkabau society in their customary law teritory, there are several cases settled by discussion between heirs, community, family, custom chief until District Court: in Jurisprudence Number $39 \mathrm{~K} / \mathrm{Sip} / 1968$ on February $12^{\text {th }}, 1968$ concerning rice mill. Cases between Kalek woman (Pisang tribe, Negeri Batipuh Baruh, Padang panjang) fill lawsuit for herself and as mother for her little children (Zulkarnaini, Zulfahmi, Murni, Ana and Murdatiwarni). She was a widow whose husband late Ibrahim with title Datuk Mudo against Abdul Rahman with title Datuk Mudo (mamak heirs in their ethnic) along with Nursiah and Nursilah and the three of them were Koto tribe, Negeri Batipuh Ateh, padang Panjang. Supreme Court decision in appeal level decided the case won by Kalek woman as a widow of late Ibrahim with title Datuk Mudo for an inheritance in form of rice mill.

Based on Jurisprudence Number $39 \mathrm{~K} / \mathrm{Sip} /$ 1968 on February $12^{\text {th }}, 1968$ that a father or husband is not responsible for their children because of marriage form semendo bertandang, where a father or husband is just considered as

10 Ellyne Dwi Poespasari, "Perkembangan Norma Hukum Adat Berdasarkan Yurisprudensi Mahkamah Agung (Putusan Hakim)", Jurnal Media dan Peradilan, Vol. 1 No. 2, July 2015. guest. Therefore, children will be wife or wife's family responsibility. In other words, children just have relation with mother or mother's family, so children become heirs of their mother, not from their father.

The result of this research leads to the conclusion that husband's wages are given to wife and children not for their nephew or niece, meanwhile for estate is used for tribe member interest. Specially for estate of parents wages are given to their children not for nephew or niece. Hence, when a husband passes away, his wife and children will be the heirs. The amount of estate distribution between daughter and son is daughter gets higher amount than son.

Essentially, Jurisprudence in Indonesia has not competely given definite and constant law standard, but it has tried to give law foundation as guide for judges in taking a decision. Law standard created by jurisprudence in heredity law from pluralistic become neutral. It is because demands of the time, emancipation, and equality between Men and Women. This condition also gives impact to women who demand to release themshelves from customary law value which is discriminative between men and women. Jurisprudence also creates the same customary law value in women position (daughter and widow) as heirs.

Along with the dinamycs in customary law, society also experiences current development, especially in heredity law in Minangkabau. Minangkabau society has opened themselves and not closed any possibilities that their matrilineal system (female lineage) someday will turn into parental kinship or bilateral convenient with dreams of national customary law.

\section{Implication of Estate Distribution on Minang- kabau Society After Judge's Verdict}

Customary law has three characteristics, first, traditional, customary law based on ancestor and deity will be considered as sacred. This belief is contructed within hereditary legend/story which is written or unwritten. Second, It can change, eventhough it is traditional, customary law can change adapted with 
particular condition from community development. That change usually happens not because of legal deletion of regulation, but because there is condition, time, and place or new stipulation decided by authority institution. In this case, customary law has several characteristics such as developing and dinamycs. One significant implication from this dinamyc characteristic is pattern of judge's verdict which means any posibility of judge to give different decision on similar cases. Third, capability of customary law to adapt, customary law can receive any sugestion from outside as long as it does not against their customary law soul. Customary law can be said simple because it is humble and uncomplicated in administration. Consequently, customary law is easy to receive any sugestion, element, or influence from other laws because it is not written and not codified.

According to the concept, the development of customary law in Indonesia is based on two applied model theories, namely: first, linier model which is the development of customary law where the new customary law does not consist of the old one (This kind of development is development through judges' verdict), for example heredity law; second, interactive model which is the development of customary law where the new law still consists of the old law (This kind of development grows among the people). ${ }^{11}$

Inheritance system among matrilineal $(\mathrm{Mi}$ nangkabau) people is conducted collectively. This system is influenced by the way of thinking in tradition called as communal or togetherness way of thinking. Therefore, in Minangkabau, heirlooms are given to every related daughter as heirs of the heirlooms and the ownership cannot be divided. However, the ownership is arranged by the elders (women) on application rights. Daughters as heirs can use, try and enjoy the heirloom such as rice field and house under the supervision of elders as head of heir (wo-

11 Ellyne Dwi Poespasari, "Kedudukan Anak Perempuan Dalam Masyarakat Batak", Jurnal Program Magister Ilmu Hukum Universitas 17 Agustus 45, Vol. 10 No. 1, April 2013. men). ${ }^{12}$ Practically, heredity law in Minangkabau applied kinship system from the mother side, namely brothers and sisters, mother and their siblings either male or female, grandmother as well as their siblings either male or female and so on according to line of descent. Thus, automatically, every child earn right as heir from their own mother, both high and low heirlooms. If the one who passed away is a male (husband), the children and widow will not become the heirs for his estate but it will be for the children of his sisters.

Associated with the development of norms or legal norms of heredity law with the existence of jurisprudence from Supreme Court on matrilineal kinship system in Minangkabau, there is a development in hereditary law there. Jurisprudence Number $39 \mathrm{~K} / \mathrm{Sip} / 1986$ on February $12^{\text {th }}, 1968$ decided that a father or husband does not take responsibility of his children because of semendo bertandang marriage system where father or husband is only considered as guest; thus, the children becomes wife's or family of wife's responsibility. In other words, children only have relationship with mother and the family of their mother; thus, children become the heirs from their mother not from their father. As a result, the existence of kincir padi case signified that heredity law in Minangkabau can be solved through Court up to Supreme Court.

Related to norms or legal norms of heredity law with the existence of jurisprudence from Supreme Court/judge's verdict, there is change in division of heredity law for Minangkabau people. Therefore, those decisions from Supreme Court admit widows' position as heirs of their husband. This particular decision from Judges challenges the value of heredity law in Minangkabau which applies matrilineal kinship system that does not position widows and their children (both male and female) as heirs of his husband or father. For Minangkabau people, if

12 Achmad Haykal, Kismiyati El Karimah, S Kunto Adi Wibowo, "Konflik Pengetahuan Kepemilikan Tanah di Minangkabau" eJurnal Mahasiswa Universitas Padjadjaran, Vol. 1 No. 1, 2012, p. 2. 
there are any inheritance from husband or father, those deserve to be heirs are sisters and nephews of their husband or father. As a result, the existence of jurisprudence is a new breakthrough so there is a shift in the value of customary law from the old one to new.

\section{Conclusions}

First, benerally, people who applied customary law solve their problem with discussion. However, if every effort in discussion with family has failed, the case will be brought and proposed to the court. Second, after jurisprudence emerges, norms in heredity law among the people experience development and shift. The concept for heredity law in Minangkabau, widows are not the heirs of their husband; however, with Judges' verdict, they admit the position of widows as heirs of their husband property. Thus, Judges' verdict actually challenges norms in Minangkabau customary law which applied matrilineal kinship system. This system does not position widows and their children (both male and female) as heirs of their husband or father. Therefore, the existence of jurisprudence is a new break-through so there is a shift from the old customary law to the new one.

\section{Suggestions}

First, judicial administration in Indonesia, especially the Judges, should reconsider the position and rights between male and female in estate distribution. Therefore, in deciding heredity law, Judges have to consider parental or bilateral kinship system because that system provides equal position between male and female. Second, to Research Institutions, either in University or outside, they need to take part for a research in this case in order to help giving comment to judges' verdict associated with heredity law.

\section{References}

Abubakar, Lastuti. "Revitalisasi Hukum Adat Sebagai Sumber Hukum Dalam Membangun Sistem Hukum Indonesia". Jurnal Dinamika Hukum. Vol. 13 No. 2. May 2013. Pp. 319-330. DOI: 10.20884/1.jdh.2013.13.2. 213;

Elpha, Meriza. "Peran Datuk Pemuka Adat Sebagai Mediator Dalam Penyelesaian Sengketa Harta Pusaka (Harta Soko) Di Kabupaten Kampar". Jurnal Ilmu Hukum UNRI. Vol. 6 No. 1. August 2015-January 2016. Pp. 170-183;

Fauzi, Anwar. "Dualitas Hukum Waris Minangkabau Dan Islam (Studi Konstruksi Sosial Masyarakat Muslim Minangkabau Di Malang)". Jurisdictie. Jurnal Hukum dan Syariah. Vol. 3 No. 1. June 2012. Pp. 4554. DOI: 10.18860/j.v0i0.2180;

Fauzi, Engrina. "Dualisme Pelaksanaan Pembagian Harta Waris Di Minangkabau Dalam Persektif Hukum Islam dan Hukum Adat". Jurnal Ilmu Hukum Yustisia. Vol. 24 No 2. 2016. Pp. 211-229.;

Hadikusuma, Hilman . 1993. Hukum Waris Adat. Bandung: Citra Aditya Bakti;

Haykal, Achmad. Kismiyati El Karimah. S Kunto Adi Wibowo. "Konflik Pengetahuan Kepemilikan Tanah di Minangkabau" eJurnal Mahasiswa Universitas Padjadjaran. Vol.1 No.1. 2012. Pp.1-18;

Komari. "Eksistensi Hukum Waris Di Indonesia: Antara Adat dan syariat”. Jurnal Asy-Syari'ah. Vol.17 No. 2. August 2015. Pp. 157172;

Marzuki, Peter Mahmud. 2005. Penelitian Hukum. Jakarta: Prenada;

Poespasari, Ellyne Dwi. "Kedudukan Anak Perempuan Dalam Masyarakat Batak", Jurnal Program Magister Ilmu Hukum Universitas 17 Agustus 45. Vol. 10 No. 1. 2013. Pp. 32-41;

Poespasari, Ellyne Dwi. "Perkembangan Norma Hukum Adat Berdasarkan Yurisprudensi Mahkamah Agung (Putusan Hakim)". Jurnal Media dan Peradilan. Vol. 1 No. 2. 2015. Pp. 20-24;

Soepomo. 2003. Bab-Bab Tentang Hukum Adat. Jakarta: Pradnya Paramita. 